
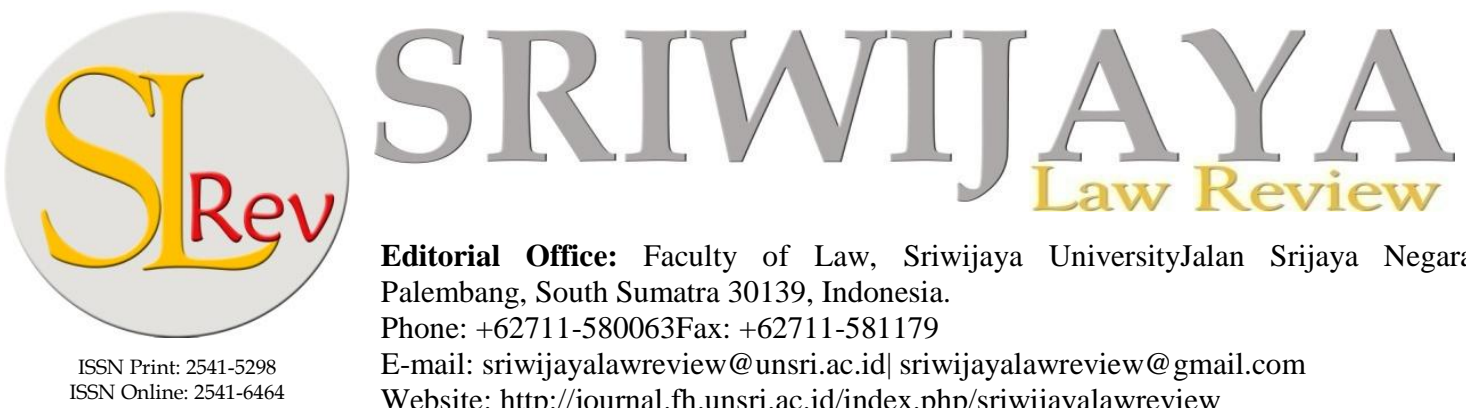

Editorial Office: Faculty of Law, Sriwijaya UniversityJalan Srijaya Negara, Palembang, South Sumatra 30139, Indonesia. Phone: +62711-580063Fax: +62711-581179

E-mail: sriwijayalawreview@unsri.ac.id| sriwijayalawreview@gmail.com Website: http://journal.fh.unsri.ac.id/index.php/sriwijayalawreview

\title{
The Reform of the Procedural Religious Court Law Based on Islamic Law in Indonesian Legal System
}

\begin{abstract}
Abdullah Gofar ${ }^{1}$
Abstract: The history of the development of religious courts and the inner atmosphere struggle of Muslims in Indonesia which faced the state's political force in the New Order era has brought forth the religious procedural law. Article 54 of The 1989 Law No.7 stated that "the applicable law in the Religious Courts are applicable procedural law in the General Court, except those specifically regulated in this law." Philosophically, the Western law both civil substantive law (Burgerlijke Wetboek) and formal law/civil procedure (HIR and $R b g$ ), prepared using the approach of individualism, secular, the optical properties of the nature legal dispute was seen as objects (Zaak) which is sheer material. While the substantive law in religious courts is the law derived from Islamic law that stem from philosophical values of Islam. So, the presence of the Religious Courts in the scope of judicial in Indonesia still raises problems, including: Why is the western law of civil procedure which promote the value of materialism and formal correctness adopted into religious procedural law, whereas the philosophical orientation is not aligned with the substantive law based on Islamic law, and what are the efforts to reform the reformulation of procedural law of religious courts.
\end{abstract}

Keywords: islamic law; legal system; religious courts; religious procedural law; supreme court.

\section{ARTICLE HISTORY :}

Received: Apr 11, 2017;

Reviewed: June 16, 2017;

Accepted: July 11, 2017;

Published: July 31, 2017.

1 Faculty of Law, Sriwijaya University, Palembang-South Sumatera, Indonesia E-mail: abdullahgofar12@yahoo.co.id

\section{INTRODUCTION}

The history of the development of religious courts and the inner atmosphere struggle of Muslims in Indonesia which faced the state's political force in the New Order era has brought forth the reli- gious courts law ${ }^{1}$. Ratification of The 1989 Law No.7 on the Religious Courts was done for the first time in postindependence and it specifically regulates the scope of authority of religious courts and put it equal with other judicial bodies under the authority of the Supreme Court. But the birth of the religious courts law remains leaving the homework that must be fought especially Religious procedural law. Article 54 of The 1989 Law No.7 stated that "the applicable law in the Religious Courts is applicable procedural

\footnotetext{
${ }^{1}$ Abdulah Gani Abdullah, 1993, Justice Legislation Religion In The Pulpit Law No. 8 Year IV, 1993, Jakarta, Ministry of Religious Affairs Al-Hikmah, pp 42-48.
} 
law in the General Court, except those specifically regulated in this law".

It can be understood, based on the formula, that the procedural law in the religious courts practices civil procedural law applicable in the High Court or tribunal in resolving disputes. Civil procedural law applicable in the court and the high court is none other than The Revised Inland Regulations (HIR/Het Herziene Inlands Reglement) ${ }^{2}$ and The Civil Procedure Applied in the areas Outside Java and Madura which is known as $\mathrm{RBg} /$ Rechts Reglement Buiten gewesten sourced from the Civil Procedure (BRV/Burgerlijke Rechts Vordering), the Netherlands Civil Procedure Law, which was born in the 19th century AD. Philosophically, Western law both civil substantive law (Civil Code/Burgerlijke Wetboek) and formal law/civil procedure (HIR and $\mathrm{Rbg}$ ), were constructed using the approach of individualism, secular, the nature of the legal dispute was seen as objects (zaak) which was sheer material.

While the material law in religious courts is the law derived from Islamic law that stem from philosophical values of Islam. The concept of sharia Islamic law is grouped in worship and sharia mиаmalah and do not specify the dichotomous terms of law into public law and private law, so that in practice, the application of sharia muamalah ${ }^{3}$ cannot be classified only to the realm of civil law. This means that the substantive legal field is under the authority of religious courts,

\footnotetext{
2 The Dutch regulation that applied in Java, and Madura.

3 The Islamic laws that applies to the human to human interaction.
}

which are related to the field of family law in which there are laws on marriage, inheritance law and other fields, and not everything can be done with a civil approach, because in certain circumstances there are religious values that should be of concern.

So when the western law of civil procedure (HIR and $R B g$ ) was used as a religious procedural law, it is not very precise, because the concern in certain circumstances contains religious values while the enforceability of western civil procedure has also been distanced from the value of sharia Islam as its philosophical basis. Since 1989, HIR and RBg have been used as a religious procedural law, meaning within 27 years Indonesian Muslims have struggled to resolve legal issues in the religious court in the frame of Western law, and until now there are no signs of an attempt to alter or replace the religious procedural law which is based on the value of Islamic law into the statute of a national legal system.

The history of religious court (formerly the Syariah Court) has developed as old as the advent of Islam in the archipelago. During the Dutch Trading Company (VOC/Vereenigde Oostindische Compagnie) period between 1596 or 1602 to the 1820 s, the Islamic community at that time resolved disputes any matters in family law by law which was based on Islamic law. Even $V O C$ did not impose the rule of ship law (the law derived from the Ancient Dutch law and Roman law) applied to Moslems in Nusantara/The Netherlands Indies. However, when the Dutch Colonial Government took control of the VOC, the Dutch legal politics be- 
gan to emerge, which led to a negative stigma against religious court at that time, as For Inland Affairs Office (Voor Kantoor Inlandsche Zaken), which was inseparable with the development of Islam and Islamic law as their substantive law ${ }^{4}$.

Based on the description above, problems are posed, such as; why is western civil procedural law promoting the value of materialism and formal truth into religious procedural law, whereas the philosophical orientation is not aligned with the substantive law based on Islamic law? What is the reformulation effort to reform the religious procedural law to keep pace with the substantive law in the national legal system, and is oriented towards justice based on Islamic law and authoritative judiciary?

\section{DISCUSSION}

Western civil procedure law which is promoting the value of materialism and formal truth turns into the religious procedural law, whereas the philosophical orientation is not aligned with the substantive law based on Islamic law.

\section{Orientation of Religious Court Proce- dural Law Referring to the Spirit of Pancasila}

Legal idea (rechtsidee) which contains idea, form the basis of making the concept of law. The idea and norm construction process based on directive legal ideas (rechstidee), reflected in norms both as a basic guideline, and as an instrument re-

\footnotetext{
${ }^{4}$ Rifyal Kaaba, 1999, Islamic Law in Indonesia: Perspectives Muhammadiyah and NU, Jakarta: Yarsi University, p65. See also, Moh. Daud Ali, 1993, Islamic Law: Introduction to Law and Administration of Islamic Law in Indonesia, Jakarta: Rajawali Press, p13.
}

lated to the development of society, based on the plan expected ${ }^{5}$. A reflection of legal goals can be seen from the philosophical value as the basis for the making of legal norms reflected in the state's constitution. The role of law as a tool to build community and state with modern concepts, appeared to bring some concepts: Firstly, the legal direction and orientation to be achieved. Secondly, the legal function as a means of making up the building of habitable society and state. Thirdly, in relation to the norming process, the maximum legal norms created function can be executed ${ }^{6}$. As a guideline of life, the law should be viewed holistically well as a collection of ideas, or as a system of abstract law rules, with particular emphasis on autonomous institutions as well as tools that govern society.

The idea or legal idea (rechtsidee) is largely to achieve orderly and peaceful society and promote justice and prosperity for the people. It is therefore supported by the ethical theory which stresses that the purpose of the legal forming should give a living sense of justice in the community ${ }^{7}$. The utility theory stresses that the law can provide the maximum benefit for the community. While the mixture theory emphasizes more that the rule of law can realize the consistency among the rule of law, justice and public welfare ${ }^{8}$. All of those lead to a hope that construc-

\footnotetext{
${ }^{5}$ Hazarin, 1975, National Kinship Law, Jakarta: Tintamas , pp35-37.

${ }^{6}$ Deliar Noer, 1983, Islam, Pancasila and The Single Principle, Jakarta: Perkhidmatan Foundation, pp16-23.

${ }^{7}$ Lili Rasjidi, 1982, Basics of Philosophy of Law, Bandung: Alumni, pp42-44.

${ }^{8}$ Darji Darmodihardjo and Sidharta, 1995, Principles of Law Philosophy, (Jakarta: Gramedia), p206.
} 
tive rule of law must bring maximum benefits to society.

Legal development, formal and substantive law, must be connected with the legal idea (rechtsidee) of Pancasila. It contains a guideline and general measure of what should be seen as a law in a subsystem of living cultures in Indonesia. Rational elements of the legal idea settle into a conception of law and allow to formulate a common legal sense (Algemene rechtsbegriffen) according to what is conceived and intended by the legal idea of Pancasila. In framing the rules on top of those principles, they should impenetrate the ideas that constitute the framework of the rules to be constructed. The formed ideas as a precipitate of the principles, can be divided into two ideas, namely: First, is the idea of civil society, included in the aspects of religion and belief. Second, does the idea of the state (Staatsidee), contain about the value to be obeyed as a constitution-based agreement, as well as the steps and procedures that should be done.

In Indonesia legal state, all rules should be sourced from and describe the legal idea (rechtsidee) of Pancasila. Thus, any set of rules issued by the state, should be in a legal idea compound contents (rechtsidee) of Pancasila that shape it. Therefore, Pancasila as the fundamental norm of the state establishes legal norms under it in stages. Lower legal norms are formed and rooted in a higher legal norms, so there is no contradiction between the legal norms of higher and lower, and vice versa. It demonstrates that Pancasila as the legal idea (rechtsidee) in the legal life of the Indonesian nation moves dynamically in any legal product formation. On the one hand, Pancasila as the system of legal norms becomes the fundamental norm of the state. On the other hand, as a written rule contained in the preamble and the body of the Constitution of 1945 , it shows that the rechtsidee becomes the guiding star and legal norm system consisting of various levels of legal norms in real and concrete behavior of Indonesian people's legal life.

Although Article 29 of the Constitution of 1945 guarantees freedom of religion and guarantee the Muslims to fight to include the Islamic law into the national law, it does not necessarily mean that the entry of Islamic law classifies Indonesia as an Islamic state, but remains as a country that is based on Pancasila. Deliar Noer states there is "Islamic State" as the name, and there is a "Nation of Islam" as a concept. The Islamic State as the name is not demanded by the parties and intellectuals. The more important is the Islamic state as a concept, namely that the content and implementation of statehood are sourced and in accordance with the teachings of Islam ${ }^{9}$. Furthermore Deliar Noer asserted that the Islamic state as a concept has criteria that the Qur'an and the Hadith/Sunnah are used as guidelines in the state's life, the rule of law and the principle of consultation are run. Nevertheless, the Islamic State as the true concept can still be questioned, because it is not in the category of syariat, but of fiqih so that there is no unity of opinion about it.

\footnotetext{
${ }^{9}$ Deliar Noer, 1983, Islam, Pancasila and The Single Principle, Jakarta: Perkhidmatan Foundation, pp120-121.
} 
Hazarin directs his analysis and views in order to apply Islamic law in Indonesia not be based on Customary Law. Applicability of Islamic law according to Hazarin, should be based on legislation. Observing Hazarin's view, any interests of Islamic society that would run the legal interests must be based on Islamic law. While M.TaHIR Azhary found that nomocracy characterized as a legal state (Islam), should meet the criteria and uphold the rule of law based on Islamic law ${ }^{10}$. Each legal product in the form of laws, must accommodate the values contained in Islamic law.

His persistence and struggle in an attempt to impose Islamic law in the legal system of Indonesia, Hazairin is regarded by Daniel Lev as a figure who wants a revision of rules of Islamic law in Indonesia's legal system spectacular and radical to carry out ijtihad in order to develop their own Indonesia sect. Hazarin requires major changes to the rules that apply to Islamic societies that do not depart from the values of Islamic philosophy.

Birth of The 1989 Law No. 7 on the Religious Courts is a point of success of the struggle for equalizing Religious Courts and general judiciary. Its post enforcement, however, remains contentious, especially in the field of procedural law. Procedural law enforcement which uses a general judicial proceedings law based on $H I R$ and $R . B g$ Dutch as colonial heritage was considered very disturbing. Although in some respects as phenomena both have

\footnotetext{
${ }^{10}$ M.TaHIR Azhary, 1992, State Law: A Study on Judging Principles From The Aspect of Islamic law, Its Implementation in The Medina and The Present Period, First Edition, Jakarta: Bulan Bintang, pp79-110.
}

in common principles and norms, but it can not be denied that philosophically (nomenologi), the values of western procedural law are very different with the values of Islamic law.

Admittedly, Islamic law has been accepted as a valid system entirely for Muslims by issuing Customary Law. In other words, the new Customary Law is applicable if it does not contradict Islamic law and is limited to the material discourse on the laws set out in legislation ${ }^{11}$.

The essence of the legal responsibilities under the umbrella of legal idea (rechtsidee) of Pancasila as the development of idea of Indonesia's national law is the legal liability transcendental order which is oriented in the values of 1) the Deity; 2) Humanistic; 3) Nationality); 4) Democracy); dan 5) Social justice. Divine value has an understanding that human activity is always under the guidelines of religious teachings and beliefs. Legal idea (rechtsidee) of Pancasila has an emotional bond and legal liability transcendental. Human beings have the perfection of God's creation (ahsani Taqwim), and are trusted by God to administer the universe (khalifatullah fil ard), and have equal rights (equality). As a servant of God, man will take responsibility for all his actions in this world and hereafter.

Harmonizing the Criminal Procedural Law of the Religious and Material based on Values and Principles of Islamic Law

\footnotetext{
${ }^{11}$ Mohammad David Ali, 1996, Islamic Law: Introduction to Law and Administration of Islamic law in Indonesia, Jakarta: Raja Grafindo Persada, pp58-60.
} 
Reorientation as a step to perform religious procedural law development, is by putting a groove think departing from the legal idea (rehtsidee) of Pancasila. As a state ideology, as well as the source of all sources of law in Indonesia, Pancasila has values and legal principles of religion and belief prevailing in Indonesia, such as the value of rukhaniyah or spritualism as contained in the first principle of the "Almighty God". Authority granting to the Religious Court, as well as procedural law should not all be seen from the perspective of state administration science ${ }^{12}$. The existence of the Religious Court cannot isolate itself from general concept of law either. Yet, it is also not appropriate, if the applied procedural law, mutatis mutandis, is the law of the west.

Legal idea of Pancasila which is the integral part of the Constitution of 1945 guides each national legal development and should refer to the norms contained therein. No place for any rule to be of national law, if it is in contrary to the principles in the Constitution of 1945. The development of law that intersect to religion and belief, remains referring to Article 29 Paragraph (1) of the Constitution of 1945 which states that "the State is based on the Godhead Almighty ". That is, any legislation that is born as a derivative of the article, in substance as well as a formal law should not be out of cedar contained in the values and principles of law.

\footnotetext{
${ }^{12}$ Juhaya S. Praja in Eddi Rudiana Arief, et al, 1994, Islamic Law in Indonesia; Development and Establishment, Second printing, Bandung: Rosdakarya, pp9-10.
}

Some national substantive legal product under the authority of religious courts as reflections of Article 29 of the Constitution of 1945 are:

1. The 1974 Law No. 1 on Marriage;

2. The 1989 Law No. 7 on the Religious Courts, as amended by The 2006 Law No. 3 and The 2009 Law No. 50;

3. The 2004 Law No. 41 on Waqf;

4. The 2008 Law No. 21 on Islamic Banking;

5. The 1999 Law No. 38 on Zakat, as amended by The 2011 Law No.23;

6. The 1975 Government Regulation No.9 on the Implementing Regulations of The 1974 Law No. 1 on Marriage;

7. Government Regulation No.45 of 1990 on Divorce Procedure for Civil Servants;

8. The 1991 Presidential Instruction No.1 on the Compilation of Islamic Law implemented by the Decree of the Minister of Religion No. 154 of 1991.

The entry and development of Islamic law into national law shows that the values of Islamic law is not only recognized as a persuasive legal source, but rather an authoritative legal source. The entry of substantive value in the substantive law is guaranteed in the Constitution of 1945. The implementation of Islamic law as the law is a necessity, not a choice. Although it is not congruent with the concepts developed in the Constitution according to the Jakarta Charter, but it is necessary to pay attention that a law should negatively not be made contrary to the belief of the followers and positively it can be carried out by them and be based on Islamic law. 
The process of substantive legal enforcement of religious courts in the judicial system in Indonesia remains referring to The 2004 Law No. 48 on Judicial Power. Stages of dispute settlement authority entering religious courts were influenced by the judicial bureaucracy. Thus, there is no restriction about time and stages in the settlement process and all possible legal efforts may be carried out ranging from level of appeal to the cassation. Whereas in the case of dispute resolution in the areas of marriage there should be restriction on the stages and duration, since the dispute in marriage concerns about the lives of women, as well as their reproductive rights.

\section{Religious Procedural Law Refor- mulation in Insertion}

Observing the religious procedural law which is still leaning on $H I R$ and $R . B g$, it is time to do a reform movement through the reformulation of the existing law, although there remain a lot of formulation in $H I R$ and $R . B g$ which are in line with the general legal principles, and not in contrary with the substantive legal principles in religious courts based on Islamic law, through the legislative process. Reform and change reformulation stages can be initiated on some of the principles and norms on the inside $H I R$ and $R \cdot B g$ which are incompatible with the nature and value of the substantive law of religious courts based on Islamic legal value. Reformulation methods of religious procedural law can be carried out with the step of change as a whole.

Since Indonesia's independence until post-reform era, the construction of the civil procedure has been performed mere- ly in insertion towards the chapters as well as specific provisions in the HIR and $R . B g$. This means that the measures taken do not change the procedural law in the $H I R$ and R.Bg. When the Religious Courts were empowered and have equal responsibility with other justice agencies, since the applicable of The 1989 Law No. 7 , there has not been procedural law in particular. Settlements models are more likely to follow the mechanistic stages and procedures with long time duration. The principle of fast, simple and inexpensive trial, is not reflected in the case settlement in religious courts, particularly in the areas of marital disputes.

Reformulation of the $H I R$ and $R \cdot B g$ done in insertion is to enter the values and principles of Islamic procedural law into the chapters, as well as specific provisions. When the Religious Courts carry out the judicial process in their absolute competence, both in the areas of marriage, inheritance, zakat, infaq, shadaqoh, and Islamic economics, they remain in the corridor and the principle of Islamic law values based on the principles of simple, fast and low cost trial. However, the implementation shows difference, the formats and principles of religious procedural law remain using the $H I R$ and $R$. Bg.ones. There are merely some applicable adjustments with things prevailing in religious courts.

The religious procedural law construction in insertion towards $H I R$ and $R . B g$, confirms that in the realm of legal dogmatic, as well as definition, formulation methods, limits and system, it is unchanged. In other words, as if the values and principles of Islamic law must adapt 
to the realm of legal dogmatic based on Western law. The right thing to do is to turn up the courage to leave or cut the Western legal dogmatic that is not in accordance with the very long and procedural stages of dispute resolution into the value of the case settlement which is based on Islamic law.

\section{Reformulation of Procedural Law Re- ligious Courts in a Whole}

Legal reformulation method by doing a complete substitution of $H I R$ and $R . B g$ as religious procedural law, with the new law (ius constituendum), is a step in realizing a national law. Step and struggle to change the religious procedural law through the legislative process, require a struggle and face heavy challenges, both politically and bureaucratically. Challenges may come from internal Muslims, because not all Muslims have the same view on the importance of substituting the existing procedural law with the new one. This, could be based on the gradation and varying levels of understanding towards Islamic law, and influenced by perspectives and ideology understood in the life of the state. For secular society, therefore, using the procedural law in the $H I R$ and $R . B g$ for any dispute resolution in the Religious Courts is considered sufficient.

Externally, the challenges come from stakeholders in both government level and political party power ${ }^{13}$. As long as the not so strong rules intersect with the interests of the government and political forces, the reformulation of religious procedural law through the legislative process will face obstacles. Based on the

\footnotetext{
${ }^{13}$ Jimly Asshidieqie, 2010, About Law, Jakarta: RajaGafindo Persada, pp12-23.
}

two methods of religious procedural law reformulation, it is very possible to use the reformulation of laws method in insertion. The reason is that in reformulating it in insertion then the energy and the cost required would be fewer and lighter, when compared with the reformulation of laws method in a whole. Formulation amandement of any article in the field of procedural law, is simply to adjust to the needs in the religious courts circumstance. In other words, procedural justice which is constructed through the religious court, on the one hand remains staying on the applicable judicial system in Indonesia which carry the characteristic of Continental European judicial system . On the other hand, the values based on Islamic law are substantially maintained, so that the reformulation efforts of religious procedural law in the form of formalization and legislation are not considered urgent. The presumption is that the law of procedure under Article 54 till 91 Law No. 7 of 1989 on the Religious Courts coupled with procedural law in the $H I R$ and $R . B g$ is sufficient, and would not displace the prevailing value of Islamic law. Until recently, the religious procedural law remains are obeyed by society as a law recognized in society life.

Theoretically, in Islamic law, legal development called tajdid (renewal), is nothing new. Legal development has even become a built-in system of Islamic thinking. Rasulullah SAW had warned it in his word that says "God will send at each base of century a mujaddid who will renew His religion". Nonetheless, let tajdid be carried out with full caution so that it would not ignore the basic principles that underlie Islam. In conducting the process 
of the development of law, as well as manufacturing the rule norms process, men should be observant and serious in differentiating between basic legal rules that is ushuli (principle / foundation) and thawabit (unchangable) with a rule of law that is furu' (branches) and mutaghayyirat $(\text { mutable })^{14}$. Therefore, when there is a failure to identify these differences, then the ongoing legal rule development can be fatal to Islam as a religion and Muslims as users.

The cause of the failure may occur, due to misplaced values and principles that should be as a matter of ushuly, in fact being altered or placed into the $f u$ ru'iy and vice versa. In addition, it is important to note the social reality and the views of Islamic scholars. Since a long time ago, the significance of social reality element has been realized. The development of modern society and global in nature, cannot be reached by nash both ushuly, and even furu'iy in natures. Towards such things, a breakthrough idea to lift the reality of social life into a form of formal law is necessary, so as to keep in line with the legal value which is ushuly in nature.

Although not all people are in line with the opinion of the scholars who set urf or customs of the local community as legal support, in fact many urf have been transformed into rules which are socially obeyed by a community without being given any formal shapes. In principle, social reality can be dug up and made as a part of the legal process development, as

\footnotetext{
${ }^{14}$ Nirwan Syafrin, Liberalization of Islamic Sharia. Executive Director INSIST in Republika, Thursday, October 15, 2009.
}

long as it does not contradict the texts of the Qur'an which fall into the category of qath'iy al-thubut wa al-dilalah. Ibn 'Abidin had ever asserted: "Urf which is contrary to the nash cannot be taken into consideration". Towards the same thing, Ibn Nujaym also said: "Urf cannot be taken into consideration on the issues that have nash provision (al-mansus' alaiyh $)^{\prime \prime 15}$. Thus, social reality which transform into a habit or urf has a limit room for maneuver and cannot break through the syar'i provisions. It means that the rule primacy which is syar'i in nature cannot be exceeded by human ratio with any legal philosophy or other philosophical approaches.

If a development uses health sciences approach, then it is imposible for a preexisting disease, to be allowed to survive without any attempt to overcome or treat it. In diagnostics, towards disease that the symptom is already known, then something should be done to overcome it in order to recover the health ${ }^{16}$. So, in the legal development, the applicable supporting laws which are already known to cause non synchronized or non harmonized rules, then the steps are taken to evaluate and take action against interference with the legal rule ${ }^{17}$. Towards the applicable religious procedural law, to

\footnotetext{
${ }^{15}$ Umar Sulayman al-Ahqar, 2000, Nazariyat $f i$ Usul al-Fiqh, Beirut: Daral-Nafa'is, p199.

${ }^{16}$ Diagnostics is the science concerning how to determine the type of disease and examine the signs are there. See, the Great Dictionary of Indonesian, Jakarta: Gita Media Press, 2011 p224.

${ }^{17}$ Edy Lisdiono, 2017, "Improving Legal Argument Critically In The Litigation Mechanism In Indonesia (An Empirical Study Of Environmental Verdicts)", Sriwijaya Law Review, Vol. 1 Issue 1, January (2017).
} 
some instances the rules synchronization and harmonization do not substantially occur.

As stipulated in The 2004 Law No. 4 on Judiciary, an effort to simplify procedures for litigants in religious courts is a necessity. The divorce process, especially, should be simplified, mainly on the determination of termination time of divorce cases, any remedies to appeal and cassation are not necessary. With this current judicial mechanism, there are protracted divorce cases that take very long time resolution as a result of legal efforts, resulting in an unclear marital status of the couple involved in the case. In addition, the divorce cases submitted by the wives turned out to dominate the cases in religious courts, as a result that they only can be seen from a mechanistic procedure of the article formulation of the legislation, not from the interests of syariat whether a wife may or may not sue to divorce her husband. If the formulation of legislation is maintained, then the divorce trend and domination persist in religious courts. In addition, towards the execution of religious court decision concerning both a divorce case and other cases which include in the religious court competence need to be adapted to the character of the Islamic law philosophy as a reference, not the secular concept prevailing in western law.

Authoritative judicial is the process of realizing the law through the court system in reality (in concreto), tangible on law enforcement, standing on the provision of legal services and has a wide scope and occurs at any time ${ }^{18}$. Authoritative religious courts can be manifested through a fair process of law enforcement, based on the rule of law, the judge's behavior as law enforcer pays its attention to the social environment of the society. A just law enforcement can be achieved, if the rules of procedural and substantive laws enforced religious courts and law enforcement procedures are right and fair. A rule of law is right and fair, if it is made in a right manner, its substance is in accordance with legal awareness, and it provides the greatest benefit to the interests of many individuals and society. In other words, the rules of procedural and substantive legal of religious courts are not good, if they are made only for the sake of power and have so wide gap with the consciousness and social reality of society (situation gebundenheit).

Although the legal system in the judicial sphere remains strongly influenced by the positivistical concept, the role of the judge is expected to translate things that happen before the court with the realities happen in the community ${ }^{19}$. The judge, as a reflection of the Religious Court, has important position and role in the legal renewal. The adagium asserts that the judge is considered knowledgeable about the law (ius curia novit) of the cases submitted to him/her. The adagium contains the assumption that the the judge should have knowledge and deep and wide insight about the law until the cur-

\footnotetext{
18 Bagir Manan, 2005, Dignified Justice System (An Introduction), First Edition, Yogyakarta: UII Press, pp13-15.

${ }^{19}$ Satjipto Rahardjo, 2009, Law Enforcement: A Sociological Review, $1^{\text {st }}$ Printing, Yogyakarta: Genta Publishing.
} 
rent law. The judge should never stop learning and constantly need to update his/her knowledge and understanding of the law and its dynamics.

Role as a law reformer applies mutatis mutandis to all judges, including the judges in religious courts, ranging the trial, appellate and cassation judges. Through its position and authority, the judge may be active as the central figure of legal reform. As a legal reformer, the judge can conduct a legal discovery (rechtsvinding), a legal establishment (rechtsvorming), and a development of legislation (rechtsschepping). ${ }^{20}$ Through his/her decision, it is expected a judge is active and progressive in his/her role to reform the law. The judge should fill any legal vacuum through the use of instruments and methods of interpretation towards the textual formulation of a legislation regulation.

A religious court judge may also conduct a reinterpretation of existing interpretation. It is intended as an effort to reactualization, revitalization and even reorientation of meaning towards the textual formulation of legislation regulation in the field of substantive law of religious court, adjusted to the legal idea of Pancasila. There is no permanent and forever applicable interpretation, except an authentic interpretation which is deliberately made forever. A progressive, futuristicanticipatory interpretation can presumably be a correction towards the substance of the existing ius constitutum norm and

\footnotetext{
${ }^{20}$ Komariah Emong Sapardjaja, 2006, Justice and Legal discovery (rechtsvinding) in the Era of Reform and Transformation Law, Bandung: Citra Aditya Bakti, pp95-105.
}

contribute at once in the formulation of ius constituendum norm ${ }^{21}$.

In carrying out his/her authority, the religious court judge can perform any action which is testing the relevance of the enactment of a law, if, according to his/her value and faith the law has no relevance. In principle, the judge is authorized to get rid of or do not enforce (contralegem $)^{22}$ a law. Legal reform through the judicial process by the judge shall be felt more real (das sein) compared to the legal reform through the legislative process (das sollen). A judge should always be present, fused (involved) and existing (to-be) in the center of social life for real, without fear or worry of losing its identity as a judge and shall remain being objective, just, independent, and impartial.

When he/she needs to create any (new) law, a judge of religious court should have a moral and intellectual courage to get out of the influence and the shackle of the conventional legism grip, which think and act out of the box. The principles of propriety, expediency and justice form the most important reference source when the judge should take action to create a (new) law by using the paradigm of thinking out of the box. However, it should be recognized that for so doing is not an easy way. Sometimes he/she has to dare to use the way of thinking assymetric towards the stagnant grip of thought.

Spirit of a verdict lies in the ratio decidendi, while the crown of the judge's decision lies in its irah-irah. It does not

\footnotetext{
${ }^{21}$ Michael J.Gerdracht, 2008, The Power of Precedent, New York: Oxford University Press. ${ }^{22}$ Note 21.
} 
matter if the later decision would cause controversy, disagreement, the pros and cons in the community as well as to the litigants $^{23}$. The attitude of judge's standpoint in a case is poured in the decision handed down based on the true conviction. This is in harmony with the universal principle of the independence of the judiciary which has been constitutionally governed.

Law enforcement of authoritative religious courts as part of law enforcement can be materialized, if law making and appliying functions do not overlap. Law enforcement is not only meant to defend the law in the sense of merely repressive, but also include preventive measures. Law enforcement process can be authoritative in religious court sphere, when the judge as executor becomes law enforcer, who internally has integrity, honesty, truth, personality and attitude that grow from within himself as the executor of the judicial process. While from the external aspect, there are supervision (controlling) and clear and definite career guarantee. The quality of a good judge is necessary in order to give satisfaction to the justice seekers.

The well conducted religious court forms a prerequisite of good governance. The image of religious court cannot only be approached and dissected from the judicial institutions (inward looking), but are also strongly influenced by other fields. If a religious court is not good at running its authority, then it can be the source of law enforcement failure, as well as affect good governance. When linked with the court, it is and can be double

${ }^{23}$ Note 21 . sourced in nature, first, good governance is as a system or sub-system in the order of the court. Second, good governance is and sourced from outside the court like the regulatory system, the system of public administration, political and cultural systems. The dual nature contains the function of good governance as a condition for a good, clean and authoritative court order.

\section{CONCLUSIONS}

Based on the submitted description it can be summarized as follows: first, the struggle in delivering the Religious Court Law is greatly influenced the inner atmosphere of Muslims against the political power of the New Order. The religious procedural law orientation, which adopt normatively the procedural law in the general court sphere, namely the western law, was a reality that must be accepted at that time. When the western law is applied in the Religious court, it brings polarization and bias values, principles, norms and its process of actualization is a reality that cannot be avoided. The mechanism for settling disputes in religious court sphere is carried out and based on the values of philosophy listed in Western civil procedure law, the consequence of altering in the characteristics of the substantive law as the basis of the religious court authority.

Second, the religious procedural law which remains using the Western Civil Law (HIR and RBg) clearly has an impact on the substantive legal enforcement of religious court based on Islamic law. As a preventive measure to avoid the occurrence of a shift and bias in the exercise of authority, it is time for the religious pro- 
cedural law to do updates by making procedural law which departs from national law. The foundation and the base value of the philosophy of the procedural law should be consistent with the substantive law of Islamic law. Constitutionally, the legal system of religious court is implemented based on state idea. Enforcement of case law under the authority of religious court should be carried out within the framework of national law and in line with the legal idea of Pancasila as the state principle, and the source of all legal sources prevailing in Indonesia.

Third, reformulation of legal norms of procedural law from the aspects of values and principles, conducted by redesigning formulation adapted to the traits and characteristics of Islamic law, with due regard to the judicial principle adopted in the Indonesian judicial system. Reformulation aims to harmonize the values, principles, and legal norms contained in procedural law with the substantive law applicable in the Religious Court as an Indonesian judicial sub system. Reformulation of religious procedural law in insertion is only done to address the temporary issues. While reformulation of religious procedural law in a whole, form the effort to materialize the religious procedural law as Indonesian judicial sub system is based on legal values and principles of state legal idea of Pancasila which at the end creates more authoritative religious courts.

\section{REFERENCES}

Abdulah, Gani Abdullah. 1993. Justice Legislation Religion In The Pulpit Law
No. 8 Year IV, 1993. Jakarta. Ministry of Religious Affairs Al-Hikmah.

Ahqar, Umar Sulayman al-. 2000. Nazariyat fi Usul al-Fiqh. Beirut: DaralNafa'is.

Ali, H. Mohammad David. 1996. Islamic Law: Introduction to Law and Administration of Islamic law in Indonesia, Jakarta: Raja Grafindo Persada.

Ali, Moh. Daud. 1993. Islamic Law: Introduction to Law and Administration of Islamic Law in Indonesia. Jakarta: Rajawali Press.

Arief, Eddi Rudiana, et al. 1994. Islamic Law in Indonesia: Development and Establishment. Second printing. Bandung: Rosdakarya.

Asshidieqie, Jimly. 2010. About Law. Jakarta: Raja Gafindo Persada.

Azhary, M. Tahir. 1992. State Law: A Study on Judging Principles From The Aspect of Islamic Law, Its Implementation in The Medina and The Present Period. First Edition. Jakarta: Bulan Bintang.

Darmodihardjo, Darji and Sidharta. 1995. Principles of Law Philosophy. Jakarta: Gramedia.

Gerdracht, Michael J. 2008. The Power of Precedent. New York: Oxford University Press.

Hazarin. 1975. National Kinship Law. Jakarta: Tintamas.

Kaaba, Rifyal. 1999. Islamic Law in Indonesia: Perspectives Muhammadiyah and $N U$. Jakarta: Yarsi University.

Lisdiono, Edy. 2017. "Improving Legal Argument Critically In The Litigation Mechanism In Indonesia (An Empirical Study Of Environmental Verdicts)", Sriwijaya Law Review. Vol. 1 Issue 1. January (2017). 
Manan, Bagir. 2005. Dignified Justice System (An Introduction). First Edition, Yogyakarta: UII Press.

Noer, Deliar. 1983. Islam. Pancasila and The Single Principle. Jakarta: Perkhidmatan Foundation.

Rahardjo, Satjipto. 2009. Law Enforcement: A Sociological Review. $1^{\text {st }}$ Printing. Yogyakarta: Genta Publishing.

Rasjidi, Lili. 1982. Basics of Philosophy of Law. Bandung: Alumni.

Sapardjaja, Komariah Emong. 2006. Justice and Legal Discovery (rechtsvinding) in the Era of Reform and Transformation Law. Bandung: Citra Aditya Bakti.

Syafrin, Nirwan. Liberalization of Islamic Sharia. Executive Director INSIST in Republika. Thursday. October 15. 2009.

The Great Dictionary of Indonesian. 2011. Jakarta: Gita Media Press. 